\title{
PERBANDINGAN NYERI YANG TERJADI 24 JAM PASCA OPERASI PADA PENDERITA YANG DIBERIKAN ANESTESIA UMUM DAN ANESTESIA SPINAL
}

\author{
${ }^{1}$ Fiska M. Muhammad \\ ${ }^{2}$ Lucky Kumaat \\ ${ }^{2}$ Iddo Posangi
}

\author{
${ }^{1}$ Kandidat Skripsi Fakultas Kedokteran Universitas Sam Ratulangi Manado \\ ${ }^{2}$ Bagian Anastesi Fakultas Kedokteran Universitas Sam Ratulangi Manado \\ Email: ikha_muhammad@yahoo.com
}

\begin{abstract}
Pain can be described as an unpleasant sensory and emotional experience associated with tissue damage which has already occured or potentially will be occurred. General anesthesia is oftenly perfomed on a wide range of surgical procedures. There are two techniques of general anesthesia: inhalation anesthesia and intravenous anesthesia. Spinal anesthesia is one of the simplest and most reliable of regional anesthesia technique. This study aimed to compare the pain between general anesthesia and spinal anesthesia 24 hours post operative. This was an analytical prospective study. Samples were 24 patients consisting of 12 patients with general anesthesia and 12 patients with spinal anesthesia. The inclusion criteria were patients aged 20-60 years old, duration of operation 1-4 hours, and the operations were caesarean section and hysterectomy. The pain assessment used VAS score as well as blood pressure, pulse, and respiration. Data were statistically analyzed by using the Mann-Whitney test and showed a p-value 0.876. Conclusion: There was no significant difference in 24-hourpost-operative pain using VAS score among patients with general anesthesia and with spinal anesthesia.
\end{abstract}

Keywords: VAS scores, general anesthesia, spinal anesthesia.

\begin{abstract}
Abstrak: Nyeri dapat digambarkan sebagai suatu pengalaman sensorik dan emosional yang tidak menyenangkan yang berkaitan dengan kerusakan jaringan yang sudah atau berpotensi terjadi. Anestesia umum sering dilalukan pada berbagai macam prosedur pembedahan dan terbagi atas anestesia inhalasi dan anestesia intravena. Anestesia spinal merupakan salah satu anestesia yang paling sederhana dan paling dapat diandalkan dari tehnik anestesia regional. Penelitian ini bertujuan untuk mengetahui perbandingan nyeri pada pemberian anestesia umum dan anestesia spinal 24 jam pasca operasi. Penelitian ini menggunakan metode analitik prospektif. Terdapat 24 sampel yang terbagi atas 12 penggunaan anestesia umum dan 12 penggunaan anestesia spinal, dengan kriteria rentang umur pasien 20-60 tahun, lama operasi 14 jam serta jenis pembedahan seksio sesarea dan histerektomi. Penilaian nyeri menggunakan skor VAS serta tekanan darah, nadi dan respirasi. Data diolah dengan menggunakan program SPSS versi 20. Hasil uji statistik Mann-Whitney mendapatkan nilai $p=0,876$ yang menunjukkan tidak terdapat perbedaan bermakna dari skor VAS. 24 jam pasca operasi dengan anestesia umum dan anestesia spinal. Simpulan: Tidak terdapat perbedaan bermakna nyeri 24 jam pasca operaasi dinilai dengan skor VAS pada pemberian anestesia umum dan anestesia spinal.
\end{abstract}

Kata kunci: Skor VAS, anestesia general, anestesia spinal 
Perkembangan anestesia dalam bidang pembedahan berasal dari keinginan untuk menghilangkan rasa nyeri waktu pembedahan, tetapi kehilangan rasa nyeri bukan satu-satunya, atau bahkan merupakan tanggung jawab utama ahli anestesia modern. Tugas utamanya masa kini ialah mempertahankan jiwa penderita dalam menghadapi bahaya pembedahan; menghilangkan rasa nyeri; dan mempersiapkan penderita memasuki proses pembedahan. ${ }^{1}$

Pasca anestesia dilakukan pemulihan dan perawatan pasca operasi anestesia pada ruang pulih, yaitu rungan khusus pasca anestesia atau bedah yang berada di kompleks kamar operasi yang dilengkapi dengan tempat tidur khusus, alat pantau, alat/obat resusitasi, tenaga terampil dalam bidang resusitasi dan gawat darurat serta disupervisi oleh Dokter Spesialis Anestesiologi dan Spesialis Bedah. Ttujuan perawatan pasca anestesia atau bedah pada ruang pulih ialah: 1) Memantau secara kontinyu dan mengobati secara cepat masalah respirasi dan sirkulasi; 2) Mempertahankan kestabilan sistem respirasi dan sirkulasi; 3) Memantau perdarahan luka operasi dan 4) Mengatasi atau mengobati masalah nyeri pasca bedah. Dengan demikian pasien pasca operasi dan anestesia dapat terhindar dari komplikasi yang disebabkan karena operasi atau pengaruh dari anestesia. ${ }^{2}$

Indikasi untuk operasi sesar darurat termasuk perdarahan yang berat, seperti plasenta previa, plasenta abruption, atau ruptur uterus, prolaps atau turunnya tali pusat dan gawat janin. Dalam kasus tertentu dimana persalinan yang segera maka anestesia spinal yang paling mungkin. Dalam penelitian 22\% dari perempuan yang menerima anestesia regional membutuhkan induksi intraoperatif dari anestesia umum. Para penulis menyimpulkan bahwa anestesia spinal ialah teknik anestesia yang disukai untuk sesar elektif. $^{3}$

Anestesia umum dan operasi mungkin akan disertai oleh sejumlah gangguan fisiologis yang memengaruhi berbagai sistem organ; yang paling umum ialah mual dan muntah pasca operasi (PONV), hipoksia, hipotermia, dan ketidakstabilan kardiovaskuler. Pada tahun 2002, Studi Pemantauan Insiden Australia (AIMS) melaporkan gangguan napas (183 43\%) dan gangguan kardiovaskuler (99 24\%) merupakan mayoritas dari 419 insiden di ruang pemulihan. Setiap upaya harus dilakukan untuk memastikan kondisi optimal sebelum dimulainya anetesia dan mengikuti langkah-langkah yang bertujuan untuk mencegah komplikasi ini. ${ }^{4}$

Menurut International Association for the Study of pain (IASP) Task Force, 1994, nyeri dapat digambarkan sebagai "suatu pengalaman sensorik dan emosional yang tidak menyenangkan yang berkaitan dengan kerusakan jaringan yang sudah atau berpotensi terjadi, atau dijelaskan berdasarkan kerusakan tersebut.” Nyeri dapat diklasifikasikan berdasarkan patofisiologi, etiologi, dan lokasi. Klasifikasi tersebut dapat bermanfaat dalam pemilihan perawatan modalitas dan pengobatan. Ketika nyeri pasca operasi tidak terkontrol dapat menimbulkan efek nyeri akut seperti respon fisiologik yang lama dan menimbulkan efek kronis seperti pemulihan yang panjang dan dapat menjadi nyeri kronis. ${ }^{5-6}$

Penilaian derajat nyeri dapat dilakukan dengan penilaian kuantifikasi dan kualitatif. Penilaian kuantifikasi mengunakan skor penilaian Visual Analog Scale (VAS), penilaian fungsional, dan pengukuran biologis. Penilaian kualitatif dengan melihat penampilan pasien, meminta pasien untuk menjelaskan rasa sakitnya, dan nilai nyeri untuk memastikan analgesia yang tepat. $^{7}$

Mayoritas nyeri pasca operasi cirinya ialah nosiseptif tetapi sebagian kecil pasien dapat mengalami nyeri neuropatik pasca operasi. Nyeri nosiseptif merespon terbaik terhadap opioid dan obat antiinflamasi nonsteroid (NSAID) yang telah terbukti efektif dalam pengobatan nyeri pasca operasi. Selain itu, bila menggunakan opioid secara signifikan dapat mengurangi kejadian efek samping mual muntah pasca operasi dan 
sedasi. NSAID sepereti keterolac biasanya digunakan sebagai bagian dari pendekatan multimodal untuk penanganan nyeri perioperatif akut. $^{8}$

Penelitian ini bertujuan untuk mengetahui perbandingan efek dari anestesia umum dan anestesia spinal pada keluhan nyeri 24 jam pasca operasi abdomen

\section{METODE PENELITIAN}

Jenis penelitian ini analitik prospektif. Subyek penelitian ialah seluruh pasien pasca operasi abdomen dengan anastesi umum dan spinal di RSUP Prof. Dr. R. D. Kandou Manado. Tempat penelitian di laksanakan di RSU Prof. dr. R.D. Kandou Manado. Penelitian ini dilaksanakan pada bulan November 2014 sampai dengan Desember 2014.

\section{HASIL PENELITIAN}

Jumlah subjek penelitian 24 orang yang terbagi menjadi 2 kelompok yaitu kelompok anestesia umum dan anestesia spinal, dengan masing - masing 12 subjek tiap kelompok. Tabel 1 menjelaskan bahwa terdiri atas 12 pasien (50\%) dengan anastesi umum dan 12 pasien (50\%) dengan anastesi spinal.

Tabel 1. Distribusi Berdasarkan Jenis Anastesi Responden

\begin{tabular}{ccc}
\hline Jenis Anastesi & $\mathrm{n}$ & $\%$ \\
\hline General Anastesi & 12 & 50 \\
Spinal Anastesi & 12 & 50 \\
Total & 24 & 100 \\
\hline
\end{tabular}

Tabel 2 menjelaskan bahwa sebagian besar responden berumur 26-35 tahun dengan jumlah 10 responden (41,7\%) sedangkan yang paling sedikit kategori umur 46-55 tahun dengan jumlah 2 responden $(8,3 \%)$.

Tabel 3 menjelaskan bahwa rata-rata tekanan darah sistolik (TDS) kelompok anestesia umum 125,83, dan sistolik untuk kelompok anestesia spinal 118,33. Rata rata tekanan darah diastolik (TDD) kelompok anestesia umum 80,91, dan tekanan darah diastolik kelompok anestesia spinal 81,67.

Tabel 2. Distribusi Berdasarkan Umur Responden

\begin{tabular}{ccc}
\hline Umur & $\mathrm{n}$ & $\%$ \\
\hline $16-25$ tahun & 5 & 20,8 \\
$26-35$ tahun & 10 & 41,7 \\
$36-45$ tahun & 7 & 29,2 \\
$46-55$ tahun & 2 & 8,3 \\
\hline Total & 24 & 100 \\
\hline
\end{tabular}

Tabel 3. Rata-rata Tekanan Darah Kelompok anestesia umum dan anestesia spinal

\begin{tabular}{lc}
\hline Variabel & Mean \\
\hline TDS Kelompok Anestesia umum & 125,83 \\
TDS Kelompok Anestesia Spinal & 118,33 \\
TDD Kelompok Anestesia umum & 80,91 \\
TDD Kelompok Anestesia Spinal & 81,67 \\
\hline
\end{tabular}

Tabel 4 menunjukkan hasil uji statistik, perbandingan tekanan darah sistolik dan diastolik pada kelompok general anestesia dan spinal anestesia. Pada tekanan darah sistolik didapatkan nilai $\mathrm{p}=0,672$, sedangkan pada tekanan darah diastolik didapatkan nilai $\mathrm{p}=0,369$. Hal ini menunjukkan tidak terdapat perbedaan yang bermakna antara tekanan darah baik tekanan darah sistolik maupun tekanan darah diastolik pada kelompok general anastesi dan spinal anastesia.

Tabel 4. Uji Statistik TD Operasi Kelompok anestesia umum dan anestesia spinal

\begin{tabular}{lc}
\hline Variabel & $\mathrm{P}$ \\
\hline TDS Kelompok Anestesia umum & 0,672 \\
TDS Kelompok Anestesia Spinal & \\
TDD Kelompok Anestesia umum & 0,369 \\
TDD Kelompok Anestesia Spinal & 0 \\
\hline
\end{tabular}

Tabel 5 menjelaskan bahwa rata-rata denyut nadi kelompok general anastesi adalah $87 \mathrm{x} / \mathrm{m}$ sedangkan rata-rata denyut nadi kelompok spinal anastesi adalah 85 $\mathrm{x} / \mathrm{m}$.

Tabel 6 memperlihatkan bahwa hasil uji statistik denyut nadi pada kelompok general anestesia dan spinal anestesia 
dengan $\mathrm{p}=0,369$. Hal ini dapat menunjukkan bahwa denyut nadi untuk kelompok general anestesia dan spinal anestesia tidak terdapat perbedaan yang bermakna.

Tabel 5. Rata-rata Denyut Nadi Kelompok anestesia umum dan anestesia spinal

\begin{tabular}{lc}
\hline Variabel & Mean \\
\hline Nadi Kelompok anestesia umum & 87 \\
Nadi Kelompok anestesia spinal & 85
\end{tabular}

Tabel 6. Uji Statistik Denyut Nadi kelompk anestesia umum dan anestesia spinal

\begin{tabular}{lc}
\hline Variabel & $\mathrm{P}$ \\
\hline $\begin{array}{l}\text { Nadi Kelompok anestesia umum } \\
\text { Nadi Kelompok anestesia spinal }\end{array}$ & 0,369 \\
\hline
\end{tabular}

Tabel 7 menunjukkan bahwa rata rata laju napas setelah 24 jam kelompok general anestesia 20,17, sedangkan laju napas kelompok spinal anestesia 20,83.

Tabel 7. Rata - rata laju napas kelompok anestesia umum dan anestesia spinal

\begin{tabular}{ll}
\hline Variabel & Mean \\
\hline Laju napas anestesia umum & 20,17 \\
Laju napas anestesia spinal & 20,83 \\
\hline
\end{tabular}

Tabel 8 menunjukkan hasil uji statistik, perbandingan laju napas kelompok general anestesia dan laju napas kelompok spinal anestesia $\mathrm{p}=0,193$. Hal ini menunjukkan bahwa tidak terdapat perbedaan yang bermakna laju napas napas kelompok general anestesia dan spinal anestesia setelah 24 jam operasi.

Tabel 8. Uji statistik laju napas kelompok anestesia umum dan anestesia spinal

\begin{tabular}{ll}
\hline Variabel & $\mathrm{P}$ \\
\hline $\begin{array}{l}\text { Laju napas anestesia umum } \\
\text { Laju napas anestesia spinal }\end{array}$ & 0,193 \\
\hline
\end{tabular}

Gambar 1 menunjukkan perbandingan skor VAS setelah 24 jam pada kelompok GA dan SA. Secara keseluruhan skor VAS pada setelah 24 jam hampir sama jika dihubungkan dengan nilai rata-rata kedua kelompok ini, seperti tersaji pada tabel 9 berikut.

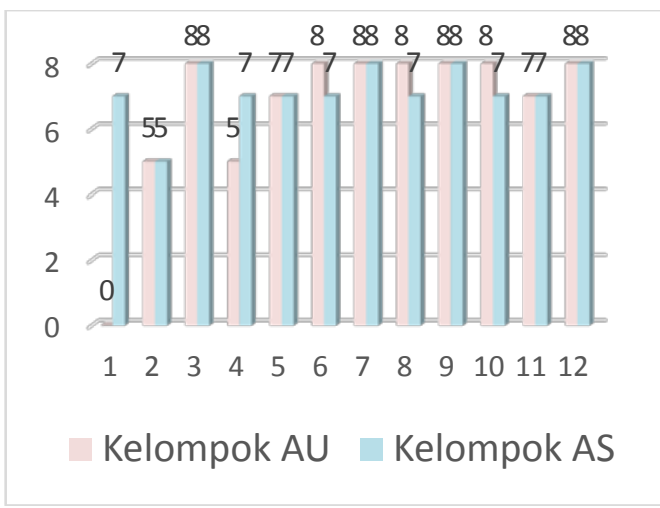

Gambar 1. Perbandingan Skor VAS Setelah 24 Jam Kelompok anestesia umum dan anestesia spinal

Tabel 9 memperlihatkan perbedaan secara keseluruhan skor VAS sebelum 24 jam kelompok AU dan AS dan skor VAS setelah 24 jam kelompok AU dan AS.

Tabel 9. Rata-rata Skor VAS Sebelum dan Setelah 24 Jam Kelompok anestesia umum dan anestesia spinal

\begin{tabular}{lc}
\hline \multicolumn{1}{c}{ Skor VAS } & Mean \\
\hline Skor VAS kelompok AU sebelum 24 Jam & 6,0 \\
Skor VAS kelompok AS sebelum 24 Jam & 5,9 \\
Skor VAS kelompok AU setelah 24 Jam & 6,67 \\
Skor VAS kelompok AS setelah 24 Jam & 7,1 \\
\hline
\end{tabular}

Tabel 10 menjelaskan tentang hasil uji statistik menggunakan Uji Mann-Whitney dimana perbandingan rerata nilai $\mathrm{p}$ skor VAS sebelum 24 Jam GA dan skor VAS sebelum 24 Jam $\mathrm{SA}$ adalah $\mathrm{p}=0,822$ $(\alpha>0,05)$ yang berarti tidak terdapat perbedaan efek dari anestesia umum (AU) dan anestesia spinal (AS) pada keluhan nyeri sebelum 24 jam pasca operasi abdomen, sedangkan perbandingan rerata nilai p skor VAS setelah 24 jam AU dan skor VAS setelah 24 jam AS dengan $\mathrm{p}=$ $0,876(\alpha>0,05)$ yang berarti tidak terdapat 
perbedaan efek dari general anestesia dan spinal anestesia pada keluhan nyeri setelah 24 jam pasca operasi abdomen.

Tabel 10. Uji Satistik Rerata Skor VAS Kelompok Sebelum dan Setelah 24 Jam

\begin{tabular}{ll}
\hline Kelompok & $\mathrm{p}$ \\
\hline Skor VAS Sebelum 24 Jam AU & \\
Skor VAS Sebelum 24 Jam AS & 0,822 \\
& \\
Skor VAS Setelah 24 Jam AU & \\
Skor VAS Setelah 24 Jam AS & 0,876 \\
\hline
\end{tabular}

\section{BAHASAN}

Pada penelitian ini sampel penelitian ialah pasien yang melakukan operasi Seksio sesaria dan Histerektomi dengan menggunakan anestesia umum (AU) dan anestesia spinal (AS) pada RSUP Prof. Dr. R. D. Kandou Manado yang dilaksanakn pada bulan November 2014 sampai Desember 2014.

Jenis anestesia yang diberikan pada responden penilitian masing-masing 12 responden (50\%) dengan AU dan 12 responden (50\%) dengan AS.

Rata - rata golongan umur kelompok anestesia umum 36 tahun dan kelompok anestesia spinal 32 tahun. Kategori umur ini merupakan kelompok kategori usia dewasa muda.

Dalam hal perbandingan tanda - tanda vital pada tabel diperoleh nilai rata - rata tekanan darah sistolik pada kelompok AU 125,83 mmHg, sedangkan tekanan darah sistolik pada kelompok AS 118,33 mmHg, dan tekanan darah untuk diastolik pada kelompok AU 80,91 mmHg, sedangkan tekanan darah diastolik pada kelompok AS 81,67 mmHg. Untuk hasil uji statistik tekanan darah sistolik kelompok AU dan AS $\mathrm{p}=0,672$, sedangkan tekanan darah diastolik kelompok AU dan AS p $=0369$. Hal ini menunjukkan tidak terdapat perbedaan bermakna antara tekanan darah baik tekanan darah sistolik maupun tekanan darah diastolik pada kelompok AU dan AS.

Perbandingan denyut nadi pada AU dan AS: nadi dengan kelompok AU 87x/m, sedangkan kelompok AS $85 \mathrm{x} / \mathrm{m}$, dengan hasil uji statistik menunjukkan nilai $\mathrm{p}=$ 0,369. Hal ini juga dapat menunjukkan bahwa denyut nadi untuk kelompok general anestesia dan spinal anestesia tidak terdapat perbedaan yang bermakna.

Untuk laju napas AU dan AS didapatkan nilai rata - rata kelompok AU adalah 20,17, sedangkan rata - rata laju napas AS 20,83, untuk hasil uji statistik didapatkan perbandingan laju napas kelompok general anestesia dan spinal anestesia $\mathrm{p}=0,193$. Hal ini juga dapat menunjukkan bahwa pada laju napas AU dan AS tidak terdapat perbedaan bermakna.

Pengukuran skala nyeri diukur melalui metode VAS sebelum 24 jam pada kelompok AU dan AS di peroleh nilai rata - rata sebesar 6 dan 5,9. Nilai ini termasuk dalam kategori nyeri sedang. Apabila dibandingkan dengan skor VAS setelah 24 jam operasi pada kelompok AU dan AS di peroleh nilai rata - rata sebesar 6,67 dan 7,71, yang masih tergolong dalam kategori nyeri sedang - berat.

Rahmatsyah $^{9}$ menyatakan bahwa tidak terdapat perbedaan bermakna tingkat nyeri pasca pembedahan penggunaan keterolak dan parecoxib sebagai premptif analgesik.

Nyeri merupakan respon langsung terhadap kejadian atau peristiwa yang tidak menyenangkan yang berhubungan dengan kerusakan jaringan, seperti luka, inflamasi. Nyeri juga dapat dikatakan sebagai perasaan sensoris dan emosional yang tidak enak dan yang berkaitan dengan (ancaman) suatu perasaan pribadi dimana ambang toleransi nyeri berbeda - beda bagi setiap orang. ${ }^{5}$

Hasil uji rata - rata skor VAS pada kelompok sebelum operasi dan setelah 24 jam operasi diperoleh nilai $\mathrm{p}=0,822$ yang berarti tidak terdapat perbedaan efektifitas dari AU dan AS pada keluhan nyeri sebelum operasi dan 24 jam setelah operasi. Sedangkan perbandingan rata - rata nilai $\mathrm{p}$ skor VAS setelah 24 jam operasi general anestesia dan spinal anestesia adalah $\mathrm{p}=$ 0,876 yang berarti tidak terdapat perbedaan efektifitas dari AU dan AS pada keluhan nyeri setelah 24 jam operasi. 
Hasil penelitian ini sejalan dengan Rahmatsyah $^{9}$ yang menyatakan tidak terdapat perbedaan yang bermakna skor VAS pasca pembedahan. Proses pemberian edukasi pada pasien juga menjadi hal yang penting sebelum dilakukan pembedahan. Pemberian informasi kepada pasien tentang nyeri pasca bedah dan penanganannya akan memberikan dampak yang baik dalam penanganan nyeri, sehingga pasien dapat mempunyai harapan tentang penanganan nyeri, sehingga pasien dapat berpikir (nyeri teratasi, bukan tanpa nyeri sama sekali). Informasi yang dapat diberikan termasuk pentingnya penanganan nyeri pasca bedah, metode - metode yang dapat dilakukan untuk penanganan nyeri pasca bedah, rutinitas pasien dalam penanganan nyeri pasca pembedahannya. $^{9}$

\section{SIMPULAN}

Berdasarkan hasil penelitian dan bahasan dapat disimpulkan bahwa tidak terdapat perbedaan bermakna antara pemberian anestesia umum dan spinal setelah 24 jam operasi dalam hal rerata skor VAS, rerata tekanan darah sistolik, rerata tekanan darah diastolik rerata denyut, dan laju napas.

\section{SARAN}

Disarankan para praktisi medis untuk memperhatikan penanganan yang baik pasca pembedahan agar dapat mengurangi respon nyeri yang dirasakan penderita.

\section{DAFTAR PUSTAKA}

1. Boulton TB, Blogg CE. In: Wulandari $W$ $\mathrm{D}$, editor. Anestesiologi (10th ed). Jakarta: Indeks, 2013; p. 4-5.

2. Mangku G, Senapathi TGA. Wiryana IM, Sinardja IK, Sujana IBG, Budiarta IG, editors. Buku ajar ilmu anestesi dan reanimasi. Jakarta: Indeks, 2010; p.138-9.

3. Chestnut DH, Dewan DM, Redick LF, Caton D, Spielman FJ. Anesthetic Management for Obstetric Hysterectomy. Journal Anesthesiology. 1989;70:607-10.

4. Miller RD, Erikson LI, Wiener JP, Young WL. Miller's anesthesia (7th ed). USA: Living stone, 2002; C 85.

5. Price SA, Wilson LM. Patofisiologi konsep klinik proses penyakit (6th ed). Jakarta: EGC, 2003; p. 1062.

6. Breivik H, Borchgrevink PC, Allen SM, Rosseland LA, Romundstad L, Hals EKB, et al. Assessment of pain. British Journal of Anaesthesia. 2008;101:17-24.

7. Keat S, Bate ST. Anaesthesia on the move. Mackinnon, Keat S, Locke T, Walker A, editors. Jakarta: Indeks, 2013; p. 93-6.

8. Arici S, Gurbet A, Turker G, Yavascaoglu B, Sahun S. Preemptive Analgesic Effect of Intravenous Paracetamol in Total Abdominal Hysterectomy. Clinical Trias-Clinic Calisma AGRI 2009;21(2):54-61.

9. Rahmatsyah. Perbandingan Efek Analgesia Parecoxib dengan Keterolak sebagai Preemptif Analgesia pada Anestesia Umum [Tesis]. Medan: Fakultas Kedokteran Universitas Sumatera Utara; 2008. 